IIII!1 総説

\title{
レチノイドの栄養学的意義に対する新しい概念： 環境因子と遺伝子の相互作用
}

\author{
四童子好広 \\ 岐阜大学医学部第一内科
}

A Novel Concept Needed for Nutritional Aspects of Retinoids :

Interaction between Environmental Factors and Genes

Yoshihiro Shidoji

First Department of Internal Medicine, Gifu University of Medicine

は じめに

生体は絶えず外界と，物質及びエネルギーを交換することによって生存を維持している。このことを，生命 は環境に依存しているという。生命活動を $1 つ$ つステムとして捉えると, それは独立栄養生物と従属栄養生 物とを問わず，環境に対して開放系（Open system）である。開放系は環境による擋乱（Perturbation）の危機 に絶えず曝されている。この危機に対処するために，生体はむしろ積極的に環境因子をシステム内に取り込み， 物質代謝やエネルギー代謝を通して，その内部恒常性を維持するために利用している1”。しかし，環境因子は 生体に対して化学物質やエネルギー源としての意義だけではないことが近年解明されつつある。ある種の環境 因子には，それに対する特異的な受容体（レセプター）が存在し，生体に対し情報としての意義を示す。物質 やエネルギーに対して開放系であった生体は，果たして情報の擋乱に対して無防備なのだろうか？

最近, 微量栄養素の 1 つであるレチノイドに対する特異的レセプターがいくつか発見された。レチノイドは これらのレセプターを介して, 種々の遺伝子の発現を調節していることが明らかにされようとしている。本稿 では，レチノイドの新しい栄養学的意義を理解するために，まず環境因子と遺伝子の相互作用に関するこれま での知見を整理し, 次にレチノイドレセプターに関する最新の知見を, 筆者らの研究も交えて紹介し, 最後に 肝細胞の機能発現におけるレチノイドの関与について考察する。

\section{I. 栄菜素と遺伝子発現}

栄養素は体内に摄取された後, 代謝され，生体構成成分（単なる構造物だけではなく，酵素などの機能たん 白も含む), またはエネルギー源として利用される。これは, 物質代謝やエネルギー代謝を考え方の中心に据 えてきた栄養学のドグマともいえるものである。

その代謝は, 前述のように環境因子を生体内部に持ち込むものであり, 物質やエネルギーレベルの内部恒常 性の維持のためには，代謝の調節が極めて重要となる。栄養素自身による代謝の調節は，3つの階層に分けて 考えると理解しやすい（表 1 )。

栄養素が体内で代謝調節に関与する場合, 生体側にその栄養素と直接相互作用する高分子（多くの場合, た ん白質）が存在する。その生体高分子と栄養素の相互作用の形式によって, 栄養素による代謝調節は以下の 3 つの階層に分かれる。最も直接的に代謝調節にかかわるのは, その栄養素の代謝反応そのものにおける基質濃 度の変動による調節である。例えば, グルコキナーゼ（GK）は, 血糖値（血中グルコース濃度）の上昇とと 
もにその活性が上昇する。グルコース は GKの基質である。しかも，GKの グルコースに対する $\mathrm{Km}$ 值が $10 \mathrm{mM}$ 以上であるのに比べて，血糖値が 5 $\mathrm{mM}$ 前後と低いので, 血糖値の上昇に 比例して酵素活性も上昇するからであ る。これは，基質と醅素の親和性の低 さが，調節系を形成していると考えて よい。いわば，基質と酵素の組み合わ せで自動的に生じる調節といえる。最 も原始的な調節である。

次に，その栄養素が関係する代謝系の醅素に，栄養素が基質以外の因子として相互作用し，その醭素活性を 変動させるのが第 II 階層の調節である。例えば，肝ホスホリラーゼ a は，グリコーゲンを分解してグルコース -6ーリン酸を生産する醳素であるが，血糖値が高い時はグルコースを結合して T 型ホスホリラーゼ a（不活性 型）となり，その酵素活性は抑制された状態になる。ところが，血糖值が低下すると T型ホスホリラーゼaは グルコースを遊離してR 型ホスホリラーゼ $\mathrm{a}$ (活性型) となり，その醳素活性はただちに上昇する。肝におけ るグルコース-6-リン酸の供給は, やがて血糖の供給に結び付くので, ホスホリラーゼ $\mathrm{a}$ のT型/ $\mathrm{R}$ 型変換は, 血糖値の変化に即座に対応する調節といえる（ホスホリラーゼbのリン酸化によるホスホリラーゼ $\mathrm{a}$ への変換 に伴う活性化も，現象的にはこのカテゴリーに入るようにみえるが，栄養素の作用点はホルモン分泌のほうに あり，もう少し持続的な調節である。これは，次に述べる第血階層の調節に入る)。

第且階層の調節系は，栄養素が遺伝子発現系に作用して，醳素たん白質や基質キャリアたん白質などの代謝 反応に直接関与する因子の量的調節を行うものや，ホルモンやサイトカインなどの生理活性物質の合成量を変 動させて，最終的に代謝調節に至るものなどである。この調節系の存在は，以前から指摘され考えられていた ものである。しかし，そのメカニズムに関する研究はあまり手が付けられず, 最近ようやく開始されたばかり である。栄養状態と遺伝子発現の変動の詳細については観察も不十分で, 未解明の点も多い。現時点では, 間 接的な影響も加えると，すべての栄養素は遺伝子発現の調節に関与しているといってよい。

その中で, 分子レベルでの解析が進んでいるのは, 多価不飽和脂肪酸による脂肪酸合成醭素遺伝子の発現抑 制，コレステロール酸化物による HMG-CoA 還元醳素遺伝子の発現抑制，グルコースによる解糖系の鍵醭素 遺伝子やインスリン遺伝子の発現誘導, 亜鉛によるメタロチオネイン遺伝子の発現誘導, 並びにビタミンDに よるオステオカルシン遺伝子の発現誘導などである ${ }^{2)}$ 。このよう, 脂質, 糖質, ミネラル, そしてビタミン など, 主栄養素と微量栄養素とにかかわりなく，遺伝子発現系に関与していることが分かる。ミネラルと遺伝 子発現調節に関する研究は，現在最も詳細に解析されている分野なので，その代表的な例を図 1 に示す。困か ら明らかなように，(1) 転写活性化（遺伝子 DNA と相互作用し，RNA ポリメラーゼ【の活性を制御)，(2) 翻 訳活性化 (mRNA と相互作用し, 翻訳過程を制御), (3) mRNA の不安定化 (mRNA と相互作用し, RNA分解 反応を制御）など，環境因子である金属元素は遺伝子発現の種々の過程で作用する〔また，最近の報告では， コリン久乏の飼料でラットを一時期飼育すると, c-myc 遺伝子の増幅が誘導されるという ${ }^{3)}$ 。この場合は，お そらく栄養素（もしくは栄養状態）が, DNA に何らかの影響を与え，DNA ポリメラーゼの機能を制御するこ 


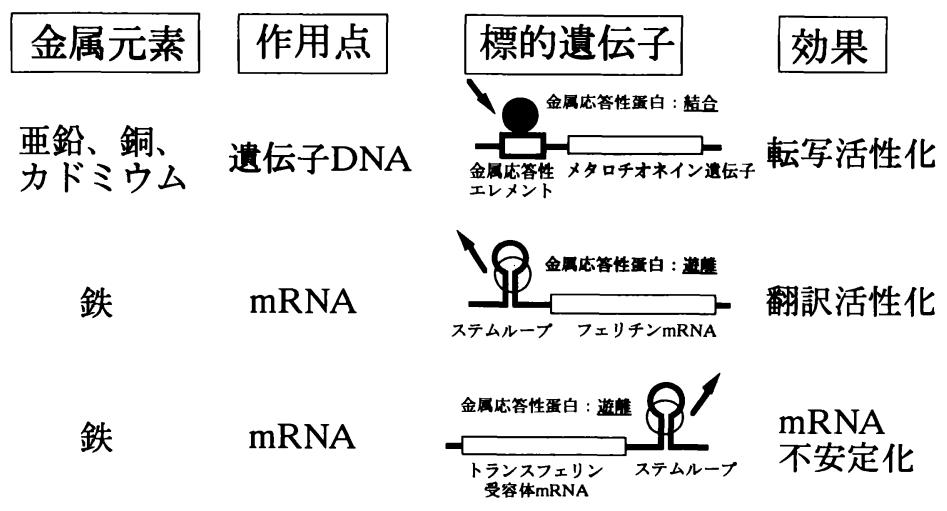

図 1 金属元素による遺伝子発現の調節

とを意味しておりこれまでに例のない栄養素と遺伝子の相互作用になる]。図 1 に示した例では，いずれの 場合も，解毒や貯蔵，細胞内への取り込みなど，各金属元素の体内代謝に対して合目的的な調節機構を成立さ せている。しかも, これらの調節は各遺伝子に特異的に備わっているものである。その特異性は, 遺伝子 DNA の中でたん白質をコードしている “構造遺伝子領域”ではなく, 通常その上流にあるたん白質をコード していない “調節領域” の塩基配列に由来する。これは, 化学反応による調節というょりは, 塩基配列“情 報”による調節と考えると理解しやすい。言い換えると, 遺伝子 DNA は環境因子に対して調節領域を設定す ることにより，環境因子の量的並びに質的変動（広義の細胞外情報）を，遺伝子発現のスイッチの ON/OFF に利用するように進化してきたことになる。このような細胞外情報に反応してその発現を変化させる遺伝子群 を誘導型の（Inductive）遺伝子と呼び, 発現調節を受けず一定の発現をしているような遺伝子を構成型の (Constitutive) 遺伝子と呼んで区別している。前者は細胞機能に特異的なものが多く, 後者は細胞の生存に必 須のものが多い。後者の遺伝子群を特にハウスキーピング遺伝子と呼ぶことがある。ハウスキーピング遺伝子 は，その上流に細胞外情報に呼応する調節領域をもたない4)。

このように栄養素は, 遺伝子の調節領域に㗢きかけて, 誘導型遺伝子の発現調節をすることが分かった。で は, 次に微量栄養素レチノイドが標的遺伝子の調節領域に働きかける場合の必須の機能素子, レチノイドレセ プターについて解説する。

\section{II.レチノイドレセプター}

生体内でレチノイドと相互作用する高分子は多数知られている。ロドプシンのようなレチノイドを共有結合 する分子を除くと，血液中の特異的転送たん白 RBP（Retinol-binding protein), 細胞内レチノイド結合たん白 CRBP (Cellular retinol-binding protein), CRABP (Cellular retinoic acid-binding protein), CRALBP (Cellular retinal-binding protein), レチノイドを代謝する酵素群, 網膜視細胞の生存因子Purpurin, 乳汁中のベータラ クトグロブリン, 涙液中の Prealbumin ${ }^{5)}$ な゙, 中にはその機能の未解明のものもある。しかし, これらはいず れも水に溶け難いレチノイドを結合し，レチノイドの体内代謝を円滑に進める因子であり，以下に述べるレチ ノイドの持つ情報を受け取る高分子（レセプター）とは趣きを異にしているようである6)。

現在見出されているレチノイドレセプターは, RAR とRXRの 2 種類に大別される。いずれも， $\alpha, \beta, \gamma$ 


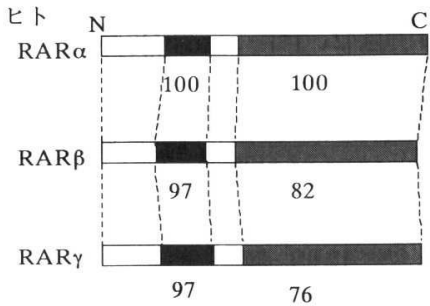

DNA結合ドメイン

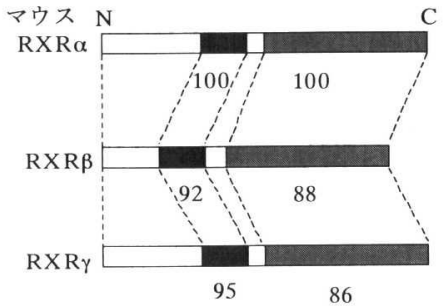

: リガンド結合ドメイン

図 2 レチノイドレセプターのドメイン構造

注）数字は各 $\alpha$ サブタイプを100とした時のアミノ酸配列の類似性を表している。

\begin{tabular}{cc|}
\hline 標的遺伝子 & RARE(retinoic acid responsive element) \\
\cline { 1 - 1 } RAR $\alpha$ & AGTTCA-gcaag-AGTTCA \\
RAR $\beta$ & GGTTCA-ccgaa-AGTTCA \\
RAR $\gamma$ & GGGTCA-ggagg-AGGTGA \\
ADH-3 & GGGTCA-ttcag-AGTTCA \\
CP-H & AGGTCA-ctgac-AGGGCA \\
CRBP I & GGTCA- aa -AGGTCA \\
& RXRE(retinoid X responsive element) \\
CRBP II & AGGTCA-c-AGGTCA-c- \\
Apo AI & AGGTCA-c-AGTTCA \\
MHC I & AGGGCA-g-GGGTCA-a-GGGTCA \\
& AGGTCA-g-GGGTGG
\end{tabular}

図 3 レチノイド答性エレメント

ADH-3, alcohol dehydrogenase-3; CP-H, complement factor $\mathrm{H}$;

MHC I, major histocompatibility complex class I

の 3 種のサブタイプが存在する。従って, 計 6 種類のレチノイドレセプター遺伝子が存在することになる。こ れらのレセプターたん白質は，いずれも核内に局在し，種々の遺伝子の発現調節をする，いわゆる転写調節因 子と考えられている。レチノイドはこれらのレセプターのリガンドになることにより，レセプターたん白の転 写調節作用を制御しているものと考えられているが，その詳細は現在精力的に研究されている ガンドはレチノイドのシス異性体であることが最近示されたが，RXR $\beta ， \gamma$ のリガンドは未同定である)。

レセプターたん白質の機能の分子下レベルでの詳細については未解明だが，レチノイドレセプターは少なく とも $2 つ の$ 機能ドメインをもっていることが明らかにされている。ペプチド鎖の中央部分にある DNA 結合ド メイン，C 末端側のリガンド結合ドメインである (図 2 )。リガンド結合ドメインは二量体形成ドメインと オーバーラップしているようだがここではその詳細には触れない。いずれにせよ，レチノイドレセプターが レチノイド濃度依存的に，標的遺伝子の転写活性化を行う場合，この 2 つのドメインは，分子下で協調的に相 互作用するものと思われる。DNA結合ドメインを介して，レチノイドレセプターはその標的遺伝子の調節領 域に結合する。調節領域の中でレチノイドレセプターの結合する部位を,レチノイド応答性エレメントと呼ぶ。 
<smiles>CC(/C=C/C1C(C)CCCC1(C)C)=C\C=C\C(C)=C\C(=O)O</smiles>

all-trans Retinoic Acid<smiles>CC(C=CC1CCCCC1(C)C)=CC=CC(C)=CCCC(=O)O</smiles>

9-cis Retinoic Acid

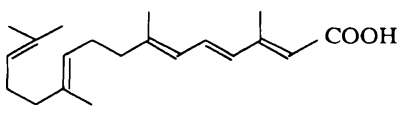

非環式レチノイド:

all-trans RA類似のコンホメーション

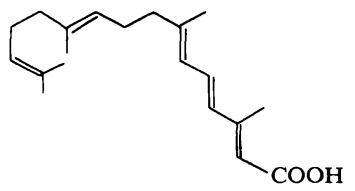

非環式レチノイド:

9-cis RA類似のコンホメーション

図 4 生理的レチノイドと非環式レチノイドの構造的対応

逆にいうと, レチノイド応答性エレメントをもつ遺伝子は, レチノイドの標的遺伝子になり得ることを示して いる。これまでに解明されたレチノイドの標的遺伝子のレチノイド応答性エレメントの塩基配列を, 図 3 に示 した。

眓から明らかなように，RAR とRXR の応答性エレメントは微妙に異なっているが，いずれも“AGGTCA” という 6 塩基配列をモチーフとした基本構造をもっている。そして，このモチーフが，1-5塩基のスペースを 置いて直接反復する，ダイレクトリピート（DR）構造を共通の特徴としている。Evans らのグループ7は, RAR 応答性エレメントはモチーフ間のスペースが 5 塩基であるのに対して，スペースが 4 塩基の場合は甲状 腺ホルモン応答性エレメントに，3 塩基の場合は活性型ビタミン $\mathrm{D}$ 応答性エレメントになることを示し, “3-4-5則”を提唱している。遺伝子発現の基本原理の一部を明らかにするような魅力あふれる仮説だが，図 3 にもあるように, 例外もあるようである。また,この “3-4-5則”に入らないステロイドホルモン応答性エレ メントは，モチーフが対称的に反復するパリンドローム構造をとる。

レチノイドレセプターの DNA 結合ドメインのアミノ酸配列は, RAR 並びにRXR の各サブタイプ間で酷似 している。このドメインは, 亜鉛をリガンドとするフィンガー構造（Zn-finger）を形成し, 図 3 に示した 種々のシスエレメントを認識し，結合するものと考えられている。

一方, 図 2 にも示したように, $\mathrm{C}$ 末端側のリガンド結合ドメインのアミノ酸配列は, 各サブタイプ間で比較 的よく保存されてはいるものの, 微妙に異なっている。この構造上の微妙な違いは, リガンドに対する結合特 異性に影響するものと思われる。実際, 橋本らは, RARのサブタイプ間で親和性の異なるレチノイドを開発 している8。ここれらの合成レチノイドはいずれも, all-trans RA とは異なり, CRABPには結合しないか, もし くは親和性が極めて低い。ところが, HL-60のような白血病細胞由来の細胞株に対して分化誘導能を示すこと から，その作用にはレセプターとの結合が重要であり，CRABP との親和性は必ずしも必須ではないことを意 味している。

一方, 武藤らは, CRABPに対する親和性を指標にして生物活性のあるレチノイドを探索し, 強い抗腫瘍作 用をもつ非環式レチノイド（図 4 ）を開発した9)。しかし、レチノイドレセプターの発見される以前に開発さ れたこの非環式レチノイドは, レチノイドレセプターに結合するか否か長い間不明であった。すなわち, 非環 


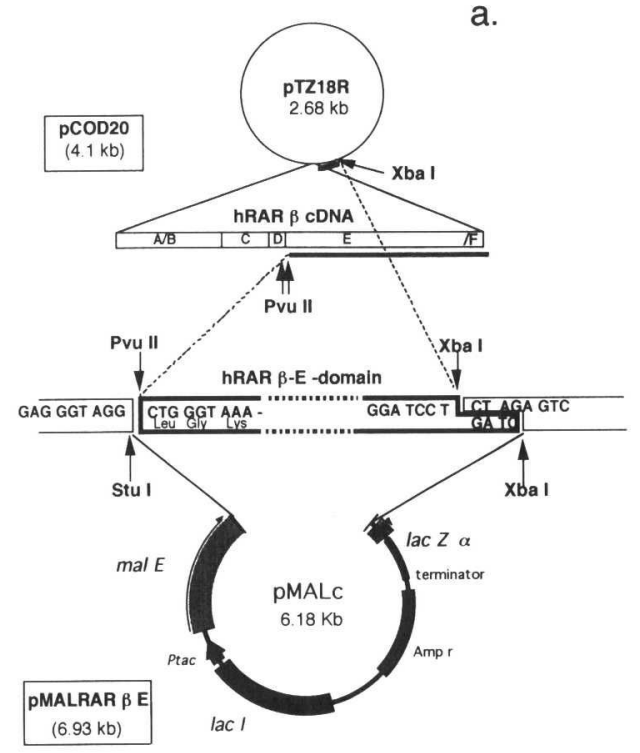

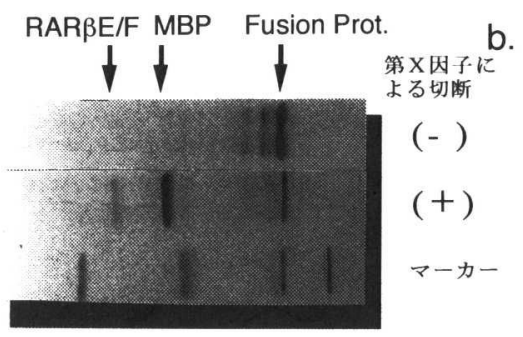

$31 \mathrm{~K} \quad 45 \mathrm{~K} \quad 68 \mathrm{~K} \quad 97 \mathrm{~K}$

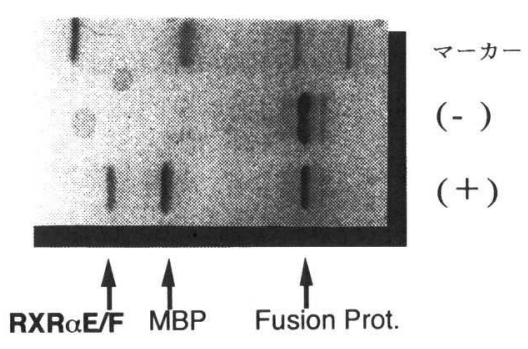

闵 $5 \mathrm{MBP} / \mathrm{RAR} \beta \mathrm{E} / \mathrm{F}$ 融合蛋白産生のためのプラズミド構築

式レチノイドの示す抗腫瘍作用は，レチノイドレセプターを介したいわゆる“レチノイド”作用かどうか不問 に付されてきたといえる。

そこで，筆者らは，組み換え型レチノイドレセプターを作製して，非環式レチノイドが結合するか否か検討 した。眓 5 に, RARßのリガンド結合ドメインを大腸菌の発現ベクターに組み換えた時のプラズミド構築を示 した。tacプロモーターの支配下に原核生物のマルトース結合たん白（MBP）の遺伝子を配置し，その下流に

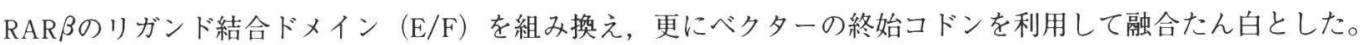

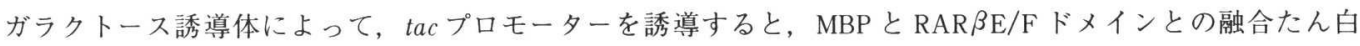
$(\mathrm{MBP} / \mathrm{RAR} \beta \mathrm{E} / \mathrm{F})$ が大量生産される。 $500 \mathrm{ml}$ ，一昼夜の培養で，およそ 0 〜 $30 \mathrm{mg}$ の融合たん白質を精製す

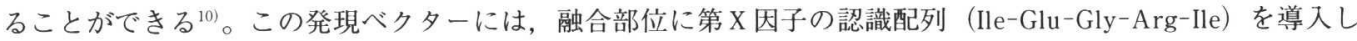
てあるので，融合たん白を精製後，第X因子により切断し，RARßのリガンド結合ドメイン部分のみを単離す ることができる (図5，b)。こうして得られた融合たん白やリガンド結合ドメインを用いて，レチノイドとの 結合実験を行った。図 6 は, 精製した MBP/RAR $\beta E / F$ 融合たん白とレチノイドの UV 吸収スペクトルを示し ている。RA (all-trans) は緩衝液に分散させた状態では，345 nm 付近に吸収極大が観察されるが, 分子吸光 係数は小さい。RA と MBP/RAR $\beta \mathrm{E} / \mathrm{F}$ 融合たん白を混合すると, $345 \mathrm{~nm}$ 付近の吸収は数倍に增大する。ちょ うど，RA を有機溶媒に溶解した場合の吸収スペクトルに近似してくる。すなわち，緩衝液中の RA が，極性 の高い環境から融合たん白質内部の疎水性領域に移行したことを示唆している。CRABPに結合したRAは, UV スペクトルに微細構造が現れることから, RA の六員環面の向きと側鎖の二重結合の向きの固定があるも のと推定されている。しかしこの融合たん白ではそのような微細構造は出現しない。RBPとRA（またはレ チノール）の結合の場合，微細構造は出現しないことから，融合たん白と RAの結合は，むしろ RBPとレチ ノイドとの結合に類似しているのかもしれない。また図には示していないが，融合たん白質のトリプトファン 

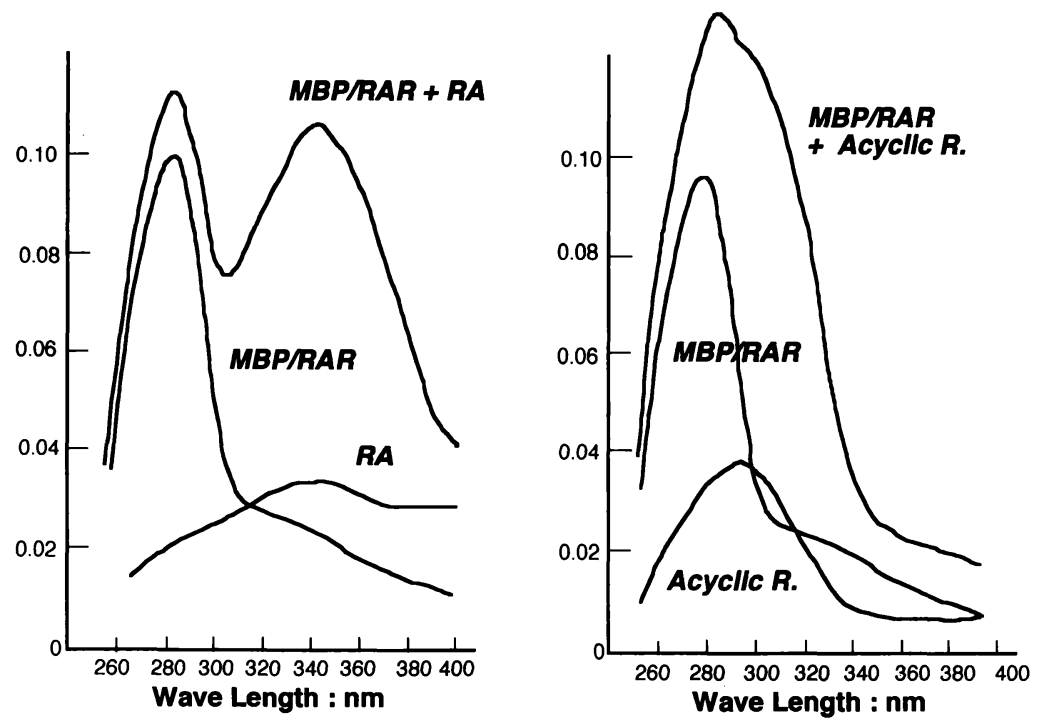

図 $6 \mathrm{MBP} / \mathrm{RAR} \beta \mathrm{E} / \mathrm{F}$ 融合蛋白とレチノイド溶液のUV吸収スペクトル

残基の内部蛍光は, RA の添加により消光する。これは, トリプトファン残基（リガンド結合ドメインに $1 つ$ ある Trp）から RA にエネルギー遷移（Energy transfer）が生起するほどにRA は Trp 残基に接近しているこ とを意味している。RBP とレチノールの結合の際にも，同様のエネルギー遷移が観察される。

一方，非環式レチノイドを緩衝液に分散させた場合は, $295 \mathrm{~nm}$ 近傍に吸収極大が観察される。図 6 に示し たように,この吸収は融合たん白の添加により数倍に増大した。RAの場合と同様に, 非環式レチノイドの微 小環境も極性の高い状態から疎水性に変化したことを意味している。非環式レチノイドの吸収極大がTrp残 基の励起波長に近いため, 融合たん白 Trp 残基の内部蛍光は全く観察されなくなる（Inner filter effect）。従 って，この場合，エネルギー遷移の測定は困難であった。いずれにせよ，MBP/RAR $\beta E / F$ 融合たん白質は， 非環式レチノイドを結合すると考えていいだろう。現在，この結合様式について詳細に検討中である。

RXR $\alpha$ は，all-trans RAを結合せず，その立体異性体である 9-cis RA（図 4 ）がリガンドとなる ${ }^{11) 。 9-c i s ~ R A ~}$ はRARにも結合することが知られているので，既に述べた組み換え型 RAR（融合たん白質）に結合性を示し た非環式レチノイドが，同様の組み換え型 RXRにも結合するかどうかに興味がもたれた。そこで，RARの場 合と同様の方法で, MBP/RXR $\alpha \mathrm{E} / \mathrm{F}$ 融合たん白質を作製した。その結果, RAR の場合と同様に, $295 \mathrm{~nm}$ 近傍 の吸光度が数倍に增大し, 非環式レチノイドは 9-cisRA と同様にMBP/RXR $\alpha \mathrm{E} / \mathrm{F}$ 融合たん白質にも結合する ことが示唆された ${ }^{10)}$ 。

レチノイドレセプターに関する筆者らの最近の研究を紹介したために，記述が詳細すぎたかもしれない。そ こで,ひとまず以上を要約すると, レチノイドはレチノイドレセプターを介して, 種々の遺伝子の発現を調節 し，そのことを通してその生理作用を発揮すると考えてよい。All-trans RAはRAR $\alpha, \beta ， \gamma$ を， 9-cis RAは RARsとRXR $\alpha$ をして，その作用を発現する。RAR とRXR の支配する遺伝子が微妙に異なることから，この 2つのレチノイドの作用は微妙に異なってくる。特に両方のレセプターに親和性を示す 9-cis RAは, レチノイ 
ドの活性型として注目される。標的細胞内での all-trans RA と9-cis RA との異性化反応, そしてその結果とし ての両異性体の量比などが, レチノイドのもつ多彩な生物作用を実現しているのであろう。All-trans RAは CRABPに結合するが，9-cis RA は結合しない。こうして，標的細胞におけるCRABP の存在も all-trans RAと 9-cis RA の量比を変えることになり, 多彩なレチノイド作用を微調整することになる。抗腫瘍作用を示し, 毒 性の低い非環式レチノイドは, 9- cis RA と同様に, RXR $\alpha$ とARsを介してその作用を発現しているものと考 えられる。ところが，9-cis RA とは異なり，CRABPに結合することから毒性が低いものと思われる。

環境因子としてのレチノイドは通常, RAの前駆体である。つまり,レチノイドはマスクされた情報として 体内に入り, 細胞内で酸化反応や異性化反応，そして CRABP などを駆使して“情報”に変換される。いわば, 内発情報のソースとしてレチノイドを摄取しているといえる。こうして, 環境因子による直接的な情報の擋乱 を防いでいるのかもしれない。次節では, レチノイドによる遺伝子発現の調節を, 肝細胞を例に挙げて考察し てみよう。

\section{III. 肝細胞特異的遗伝子の発現とレチノイド}

肝蔵は, レチノイド代謝の重要な臓器として以前から注目されてきた。それは, レチノイドの貯蔵 (Ito 細 胞）や分泌（RBP の合成）, 排泄（グルクロン酸抱合）などを一手に引き受けている臟器だからである。しか しながら, 前述の RAR P RXR が肝蔵に発現していることが報告されて以来 ${ }^{12)}$, レチノイド作用の標的臟器と しての肝臓に, 今, 関心が寄せられている。武藤らは, レチノイドレセプターが発見される以前から肝細胞癌 とレチノイドとの関係の研究に着手し ${ }^{13)}$, 最近では, レチノイドによる肝細胞癌に対する抗腫瘍作用と, 肝細 胞癌の発癌抑制に焦点を絞って研究している ${ }^{14)}$ 。そのような研究の流れの中で, レチノイドが示す肝細胞癌に 対する抗腫瘍作用は, レチノイドが肝細胞に対して生理作用をもつことを示唆しているのではないかと考える ようになってきた。しかも, この研究での特徴は, 合成レチノイドである非環式レチノイドを用いることによ ク，レチノイドの作用をより詳細に，あるいは分子医学的に解析できるようになってきたことである。以下に 述べる肝細胞の機能発現におけるレチノイドの役割に関する考え方は, 武藤及び筆者らの独自の概念であり， 未だ研究者の間で認められたものではない。そこで, 極力実験的事実とアイデアとを区別して記述するつもり である。

一般に, 癌細胞の培養液にレチノイドを添加すると, 癌細胞はその增殖が抑えられ, 分化誘導されることが 多い15)。CRABP との結合性を指標にして開発した非環式レチノイドも, 種々の癌性細胞株に対してこのよう なレチノイド作用を示す。実際, Fukutomi ら ${ }^{16)}$ は, 肝細胞癌由来の細胞株（PLC/PRF/5）を非環式レチノイ ドで処理すると， $\alpha$-fetoprotein（AFP）の発現が低下し，アルブミンの発現が増大することを見出した。

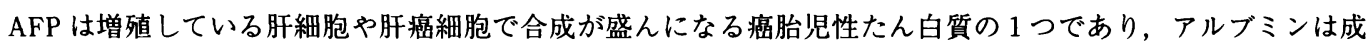
熟した肝細胞の生産する最も主要なたん白質であり,アルブミンの合成は重要な肝細胞機能の 1 つである。従 って, Fukutomi らの観察は, 非環式レチノイドが肝癌細胞の增殖を抑制し, 肝細胞機能の回復（広義の分化） を誘導したと解秎できる。つまり，非環式レチノイドは肝癌細胞に対してレチノイド作用を示したといえる。

そこで, 生理的なレチノイドである all-transRAを 2 種類の肝細胞癌由来の細胞株（PLC/PRF/5, HuH7） に添加すると, AFPの発現はいずれの細胞株においても, 非環式レチノイドの場合と同様に予測どおり抑制さ れた。ところが, アルブミンの発現は非環式レチノイドの場合とは異なり，増加するどころか逆に抑制された (図 7$)^{17)}$ 。つまり, 非環式レチノイドは, レチノイド作用を示す際, 単に生理的なレチノイドである all-trans 


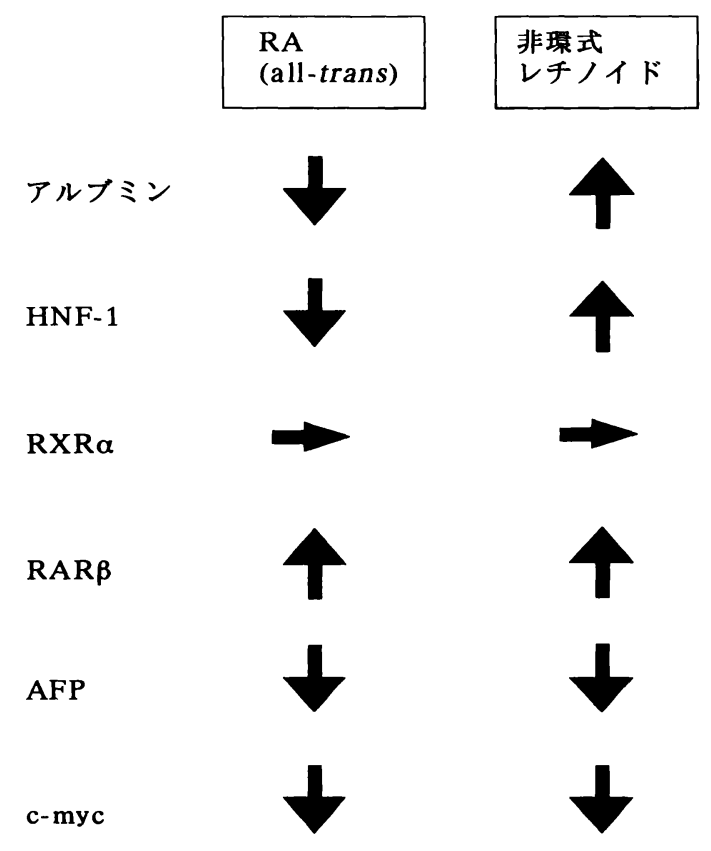

図 7 レチノイドによるメッセンジャーRNA レベルの変動

注）ヒト肝癌由来細胞株を用いた Northern Blot 解析による。

RA の模倣（あるいは代替）をしているのではないことが分かった。これはレチノイド作用を, “癌細胞の増 殖抑制と分化マーカーの回復”というワンセットの視点では解釈できないことを意味している。そこで, 単純 に増殖抑制と分化マーカーの回復を分けて解析した。

まず，增殖抑制について簡単に考察する。AFPは，確かに增殖中の肝細胞や肝癌細胞に発現する遺伝子で あるが, 細胞增殖の一般的な指標ではない。AFPはむしろ, 肝細胞特異的遺伝子産物の 1 つに数えられてい る。しかも，AFP 遺伝子は染色体上でアルブミン遺伝子とタンデムに近接していること，更にこの配置と関 連した両遺伝子発現のスイッチング機構の存在が知られていること息などを考え合わせると，アルブミン遺伝 子の発現調節と AFP 遺伝子の発現調節を分離して考えるのは必ずしも妥当ではないのかもしれない。そこで, 細胞增殖のより一般的な指標の 1 つである c-myc プロト癌遺伝子の発現を観察した。図 7 に示したように, AFPmRNAの場合と同様に, c-myc 遺伝子の発現は, 2 種類のレチノイドによって著明に抑制された。 All-trans RA による c-myc 遺伝子の発現抑制は, RAR は発現しているがRXR を発現していない HL 60 細胞や, RAR とRXR の両方を発現している HeLa 細胞でも観察されることから (筆者ら，未発表)，おそらくRARを 介した系の作動によるものと考えられる。実際，筆者らの用いた肝癌細胞株はいずれもRAR $\beta$ 発現している こと,そして非環式レチノイド並びに all-transRAのいずれもRAR $\beta$ の発現を增加させること (Up-regulation), 更に非環式レチノイドは組み換え型 RAR $\beta$ 融合たん白のリガンドになることなどの寒験結 果は, 上の考えを支持している。いずれにせよ, この両レチノイドによる c-myc 遺伝子の発現抑制は, 肝癌 細胞株の増殖抑制メカニズムの主要な部分を構成しているといってよい。

次に, アルブミン遺伝子の発現調節について考察する。既に述べたように, アルブミンの合成と分泌は肝細 胞の主要な機能の 1 つである。従って, 従来多くの研究者がこの分野に参入し, アルブミン遺伝子の発現調節 

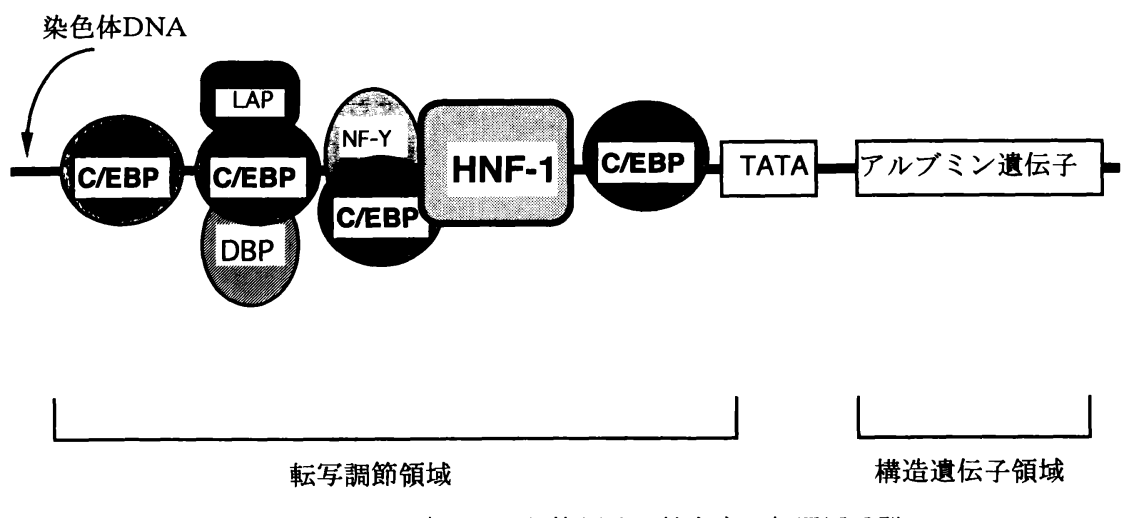

図 8 アルブミン遺伝子の調節領域に結合する転写因子群

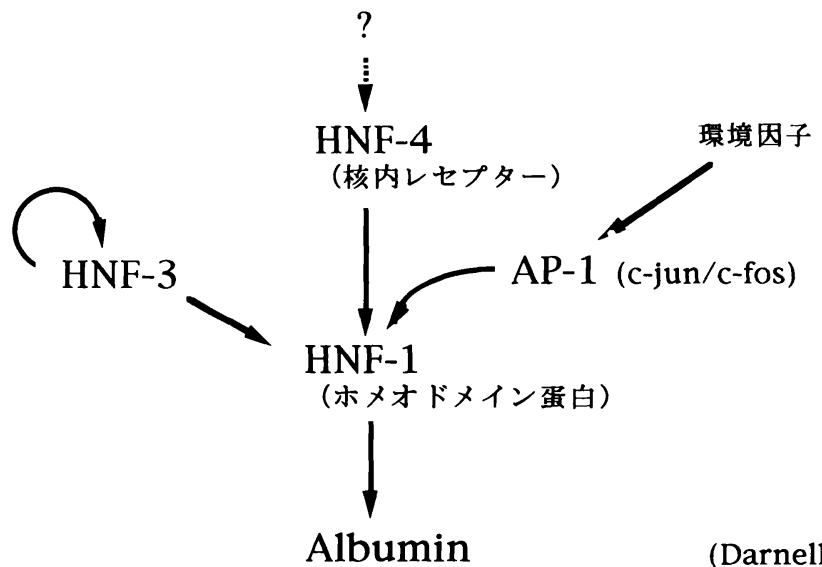

図 9 アルブミン遺伝子の発現調節における階層性

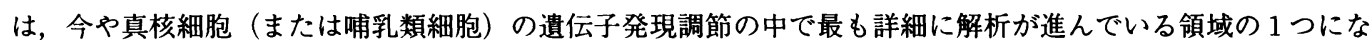
っている。そこで，まず簡単にアルブミン遺伝子の発現調節機構に関する最新のモデル ${ }^{19)}$ 紹介する。

アルブミン遺伝子は, 肝細胞に特異的に発現する遺伝子であり, 細胞の生存に必須の遺伝子ではない。この ような遺伝子は誘導型の遺伝子に分類され，構造遺伝子領域以外の部位（通常その上流）に, “調節領域”を もっていることは既に述べた。アルブミン遺伝子も例外ではない。調節領域には転写因子と呼ばれるたん白質 が結合し, 遺伝子発現の調節を行っている。アルブミン遺伝子の調節領域に結合する転写因子は, 図 8 に示し たように現在 5 種類知られている20)。その中で, HNF-1（Hepatocyte nuclear factor-1）が, アルブミン遺伝子 の転写活性化（発現）に最も重要と考えられている。このことを，ここではHNF-1 がアルブミン遺伝子の発 現を支配していると呼ぶことにする。この支配関係を矢印で示したのが図 9 である。この遺伝子支配は階層構 造を形成していて，HNF-1 遺伝子は更に上位の HNF-4 から支配されているというのが Darnell らのモデルで ある。HNF-1 遺伝子の調節領域には, 他に HNF-3 P AP-1 が結合するが, HNF-3 は HNF-1 遺伝子の転写を あまり促進しない。一方，AP-1 は，それ自身ではHNF-1 遺伝子の転写を促進しないが, HNF-4による 


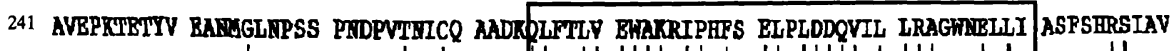

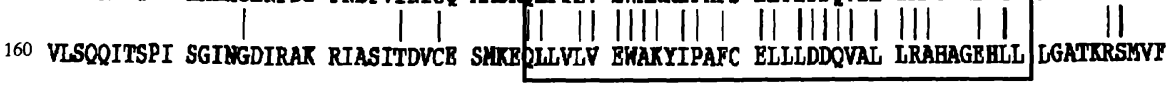

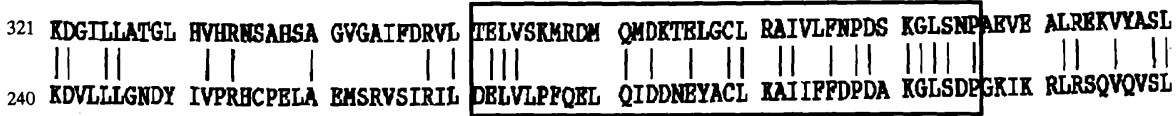
401 BAYCKHKYPB QP GRPAKLLL RLPALRSIGL KCLBELPFRR LIGDTPIDTF LMTOOA APHQ XT. ACCBPPY PCYYLSVAQG

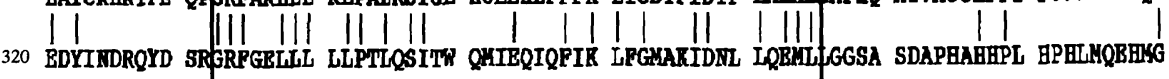

図10 リガンド結合ドメインにおけるRXR $\alpha$ と HNF-4のアミノ酸配列の類似性

注） 上の列がヒトRXR $\alpha$, 下の列がラット HNF-4のアミノ酸配列を示す。Mac Molly の相同性探索ソフ トを用い，30残基 $/ 50$ 残基許容で検出した。

HNF-1 遺伝子の転写活性化を促進する (許容効果)。従って, AP-1 と HNF-1 遺伝子とは本来の支配関係では ない。AP-1 は癌遺伝子産物の 1 つであり, その活性は発癌プロモーターによって調節されている。HNF-3の 発現は, 自己調節的ループ（HNF-3 が HNF-3 遺伝子を支配する）と, 細胞外基質により調節されていること が知られている。一方, HNF-4 遺伝子の発現調節については全く知られていない。

前に述べたように, all-trans RA はアルブミン遺伝子の発現を抑制し, 非環式レチノイドはその発現を促進 した。このような,レチノイドによるアルブミン遺伝子の両方向の発現調節を理解する場合, それが HNF-1 の発現調節を介したものかどうかを決める必要がある。そこで, レチノイド処理による HNF-1 遺伝子の発現 レベルの変動を観察すると, 図 7 に示したように, アルブミン遺伝子の発現レベルの変動と全く一致している ことが分かった。すなわち, レチノイドは, HNF-1 遺伝子の発現調節を行うことによって, 間接的にアルブ ミン遺伝子の発現調節を行っていると解釈できる。そこで, レチノイドによるアルブミン遺伝子の正と負の発 現調節をDarnell らのモデルに当てはめて考察することにした。

All-trans RA は, RAR には結合するが, RXR には結合しない。従って, all-trans RA がアルブミン遺伝子の 発現調節を行う場合, RARを介して㗢くものと思われる。ところが, Darnell らのモデルには RAR が構成因 子として入っていない。このモデルの中で RAR が相互作用することが知られている因子は AP-1 のみである。 しかも，RARはAP-1 とたん白-たん白複合体を形成することにより，AP-1 の作用を阻害することが知られ ている(クロスカップリング $)^{21)}$ 。肝癌細胞では一般に AP-1 が活性化されていることを考えると，筆者らの 観察した肝癌細胞株では, “All-trans RA はRAR $\beta$ を誘導し, 誘導されたRAR $\beta$ AP-1 を結合し, HNF-4に 対する AP-1 の許容効果を解消する” 結果, HNF-1 遺伝子の発現が抑制され, アルブミン遺伝子の発現抑制 に結び付くものと考えている。

非環式レチノイドもRAR $\beta$ に結合し，更にRAR $\beta$ を誘導したが，all-trans RA の場合と同様にRAR $\beta$ 介し て, all-trans RA の場合とは逆にHNF-1 遺伝子の発現を增加させることは考え難い。非環式レチノイドは，も

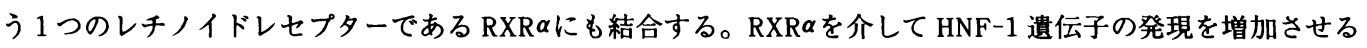
可能性が考えられる。しかし，やはり Darnell らのモデルにはRXRはは構成因子として入ってはいない。 RXR $\alpha$ とDarnellらのモデルとの唯一の接点はHNF-4である。HNF-4 は, レチノイドレセプターと同様に, 


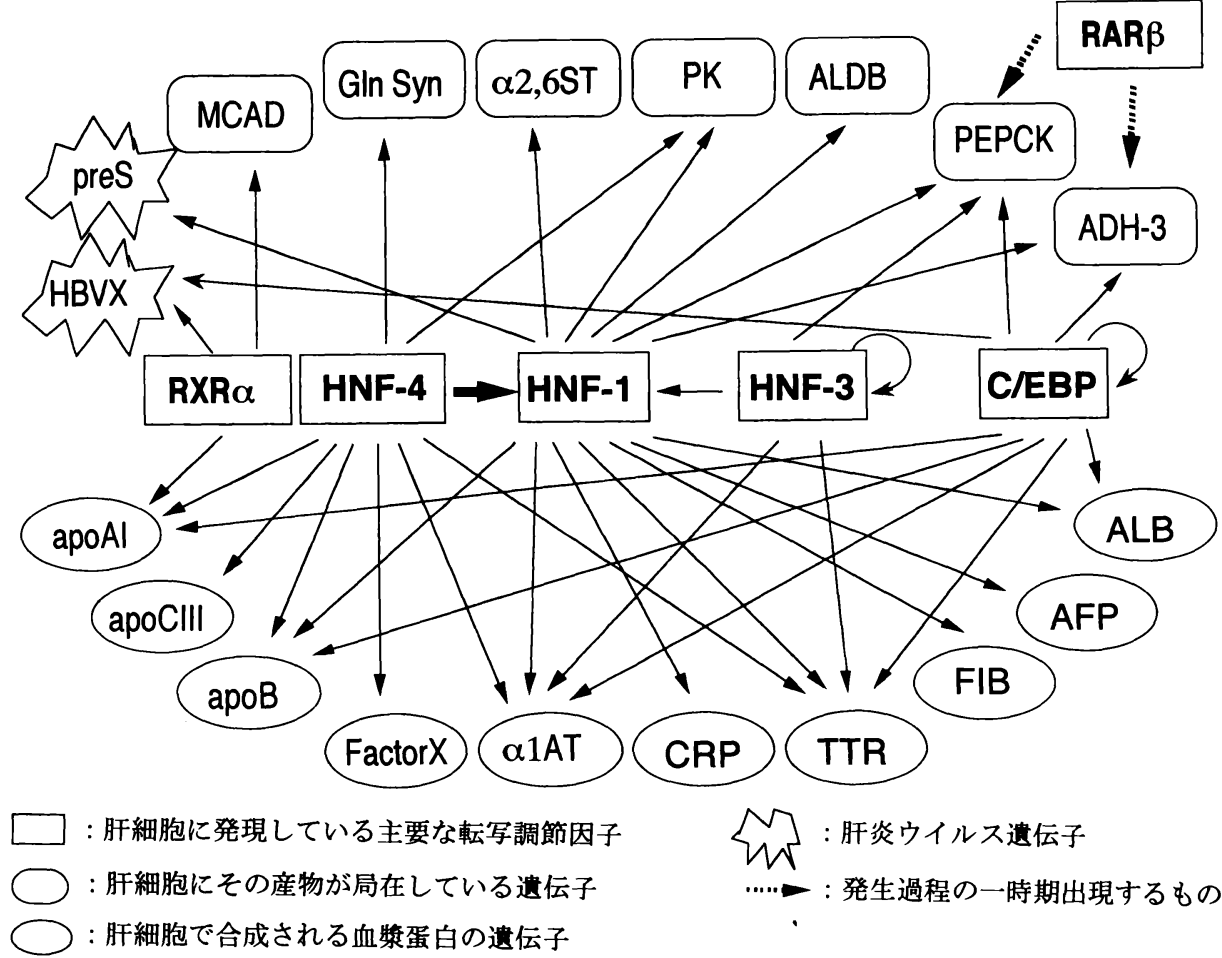

MCAD, medium chain acyl- $\mathrm{CoA}$ dehydrogenase [脂肪酸の $\beta$-酸化]; Gln Syn, glutamine synthetase $[\mathcal{P}$ ンモ二アの解毒]; $\alpha 2,6 \mathrm{ST}, \alpha 2,6$ sialyl transferase [糖蛋白代謝]; ALDB, aldolase B;PK, pyruvate kinase [解糖系]; PEPCK, phospho enolpyruvate carboxykinase [糖新生]; ADH-3, class I alcohol dehydrogenase type 3 [薬物代謝]; ALB, albumin [浸透圧]; AFP, $\alpha$-fetoprotein; FIB, fibrinogen; Factor X, [血液凝固]; TTR, transthyretin [ホルモン輸送]; apoAI, apoB, apoCIII, [脂質輸送]; CRP, c-reactive protein; $\alpha 1 \mathrm{AT}, \alpha 1$ anti trypsin [感染]

図 11 肝細胞特異的遺伝子の発現調節ネットワーク

注） 個々の遺伝子についての文献は煩雑になるので省略した。いずれも1990１992年に報告されたもの である。

肝細胞特異的遺伝子とその転写調節因子との支配関係は決して 1 対 1 に对応していない。末端の遺 伝子は複数の転写因子による支配を受け，転写因子は複数の末端の遺伝子を支配している。また， HNF-4のように末端の遺伝子と転写因子の両方を支配している転写因子もある。環境情報の変化に 対応して，主要な転写因子の発現の割合（リガンドによる活性化も含む）が変動し，それに応じて 末端遺伝子発現の質的ならびに量的変動が誘導されるものと考之られる。

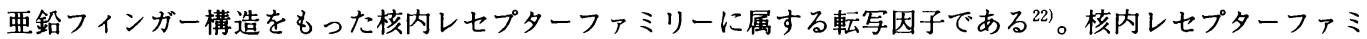
リーの他のメンバーと同様に, HNF-4 のC 末端側にはリガンド結合ドメインがあり，また二量体形成ドメイ ンともオーバーラップしている。この領域のアミノ酸配列をRXR $\alpha$ と比較したのが図10である。

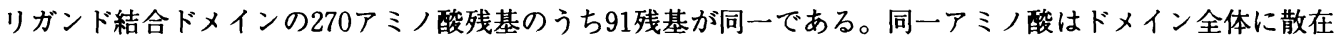
しているのではなく，3 箇所に集中して類似した部位が認められる。特に最も $\mathrm{N}$ 末端側の類似部位は, RXR $\alpha$ の Trp 残基の周辺であり, Trp 内部蛍光の解消からレチノイド結合部位の重要なサブドメインと考えられて いる部位である。従って，まず第 1 に非環式レチノイドがHNF-4のリガンドになり，HNF-1 遺伝子の発現を 活性化する可能性が考えられる。現在, 組み換え型 HNF-4 を作製し, この可能性を検討している。次に, 非 
環式レチノイドがRXR $\alpha$ のリガンドになり，RXR $\alpha$ が HNF-4 とへテロダイマーを形成して HNF-4の活性を促 進する可能性が考えられる。実際, RXR $\alpha$ は, RARやVDR (Vitamin D receptor), TR (Thyroid hormone receptor）など亜鉛フィンガー型核内レセプターファミリーの他のメンバーとへテロダイマーを形成して，そ れらの㗢きを強めることが知られている ${ }^{23)}$ 。更に, 第 3 の可能性として, RXR $\alpha$ が HNF-4 の転写因子となって いる可能性が考えられる。筆者らの最近の観察では, RXR $\alpha$ の生理的リガンドと考えられている 9-cis RAが, 非環式レチノイドと同様に HNF-1 並びにアルブミン遺伝子の発現を高めている（Yamada, Y., Shidoji, Y.ら, 投稿中)。この実験結果は, 上の 3 つの仮説のいずれとも矛盾しないものであるが, アルブミン遺伝子発現の 調節にRXR垛くかかわっていることを示唆している。

ここ数年の間, 肝細胞特異的遺伝子の発現調節に関する報告が相次いでいる。それらをすべて網羅してここ に示すことはあまりに複雑すぎる。転写因子を上に述べた RAR $\beta, \mathrm{RXR} \alpha, \mathrm{HNF}-4, \mathrm{HNF}-1, \mathrm{HNF}-3$ と本稿で は触れなかった $\mathrm{C} / \mathrm{EBP}^{24)}$ の 6 種類に絞って，それらが支配する遺伝子をネットワークの形で図11に示した。 肝細胞はこれらの遺伝子を質的並びに量的に調整することによって，肝細胞の特徴を実現している。環境因子 が情報としてこれらのネットワークに加わっているという証拠は個体レベルでは未だない。しかし，図に示し た肝細胞特異的遺伝子がすべての肝細胞に一様に発現しているというわけではなく, 例えばアルブミン遺伝子 は門脈周囲の肝細胞でその発現が高く ${ }^{25)}$, アンモニア処理の重要な酵素, グルタミン合成酵素 (GIn Syn) の

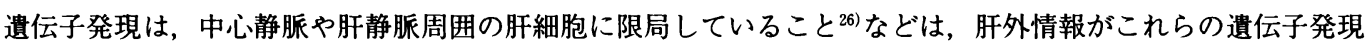
を調節していることを示唆している。肝細胞は決して一様ではなく，肝臓の中の部位によって受け取る情報が 異なり，その情報に応じて遺伝子発現の様相を変えているのである。

\section{おわりに}

かつて, ビタミン研究は“補酵素の時代”と呼ばれる時期があった。1928～1943年の15年間に, 10人以上の 科学者が何らかの形でビタミンに関係した業績でノーベル賞を受賞した。これは, 戦争がもたらした栄養素欠 そ症が引き金になったと一般には考えられている。しかし，科学史的には1907年にノーべル賞を受賞した Buchner, E.が酵素を生化学的に解析できることを示したことと切り離して考えることはできない。Watson， J., Crick, F., Wilkins, M.によって遺伝子の物質的基盤が明らかにされ（1962年，ノーベル賞受賞），その 後, 遺伝情報の解読が一段落し, 今, 遺伝子発現の調節機構が分子レベルで明らかにされようとしている。か つての補酵素の時代, 解糖系や TCA サイクルなどの代謝調節に水溶性ビタミンが重要な役割を果たしている ことが明らかにされた。ここに遺伝子の時代を迎えて，その発現調節に再びビタミンが重要な役割を果たして いる可能性が示されようとしている。社会的には，栄養素欠乏症が代謝研究の引き金になったように，遺伝子 発現の研究には, 癌という遺伝子の病気の解決への期待が大きな駆動力になっている ${ }^{27)}$ 。21世紀を前にして, レチノイドの栄養学的意義に新しい，そして大きな 1 ページが加えられることは疑う余地もない。

ここで示した実験結果はすべて岐皁大学医学部第一内科で行ったものです。稿を終えるに当たり，本草稿を 校閲していただいた武藤泰敏教授, 執筆の機会を与えて下さった細谷憲政 東京大学名誉教授, 奥 恒行 東 京大学講師に感謝致します。 


\section{文献}

1）四童子好広, 堤ちはる：物質代謝の調節（第 4 章）/奥 恒行, 高橋正侑編：「生化学」(1992）南江堂, 東京

2) Clarke, S. and Abraham, S. : Gene expression : nutrient control of pre-and posttranscriptional events, FASEB J. 6, 3146 3152 (1992)

3) Chandar, N. et al. : c-myc gene amplification during hepatocarcinogenesis by a choline-devoid diet, Proc. Natl. Acad. Sci. USA, 86, 2703 2707 (1989)

4) Alberts, D. et al. : Control of gene expression (Chapter 10), in Molecular Biology of Cell (1989) Garland Pub., New York

5) Redl, B. et al. : cDNA cloning and sequencing reveals human tear prealbumin to be a member of the lipophilic-ligand carrier protein superfamily, J. Biol. Chem., 267, 20282 20287 (1992)

6）四童子好広：ビタミンAレセプター，ビタミン，62, 358３60 (1988)

7）梅園和彦，他：新たな核内レチノイドレセプター，RXR，実験医学，10，35４1（1992）

8) Hashimoto, Y. : Retinobenzoic acids and nuclear retinoic acid receptor, Cell Struc. Func. 16, 113 123 (1991)

9) Muto, Y. and Moriwaki, H. : Antitumor activity of vitamin A and its derivatives, J. Natl. Cancer Inst., 73, 1389 1393 (1984)

10) Shidoji, Y. et. al, : 投稿準備中

11) Levin, A. et al, : 9-cis retinoic acid stereoisomer binds and activates the nuclear receptor RXR $\alpha$, Nature, 355, 359 361 (1992)

12) Mangelsdorf, D. et al. : Nuclear receptor that identifies a novel retinoic acid response pathway, Nature, 345, 224 229 (1990)

13）武藤泰敏, 他 : 原発性肝癌における cytosol retinoic acid-binding protein (CRABP) の発現, 肝臓, 18, 370 (1977)

14) Muto, Y. et al. : Present status of research on cancer chemoprevention in Japan, Jpn. J. Clin. Oncol., 20, 219 224 (1990)

15) De Luca, L. : Retinoids and their receptors in differentiation, embryogenesis, and neoplasia, FASEB J. 5, 2924 2933 (1991)

16) Fukutomi, Y. et al. : Inhibitory effects of acyclic retinoid (polyprenoic acid) and its hydroxy derivative on cell growth and on secretion of $\alpha$-fetoprotein in human hepatomaderived cell line (PLC/PRF/5), Jpn. J. Cancer Res., 81，1281 1285（1990)

17) Yamada, Y., Shidoji, Y. et al. : 投稿中

18) Nakata, K. et al. : A possible mechanism of inverse developmental regulation of $\alpha$-fetoprotein and albumin genes, J. Biol. Chem., 267, 1331 1334 (1992)

19) Kuo, C. et al. : A transcriptional hierarchy involved in mammalian cell-type specification, Nature, $\mathbf{3 5 5}$, 457 461 (1992)

20) De Simone, V. and Cortese, R. : Transcription factors and liver-specific genes, Biochim. Biophys. Acta, 1132, 119 126 (1992)

21) Shule, R. et. al. : Retinoic acid is a negative regulator of Ap-1-responsive genes, Proc. Natl. Acad. Sci. USA, 88, 6092 6096 (1991)

22) Sladek, F. et al. : Liver-enriched transcription factor HNF-4 is a novel member of the steroid hormone receptor superfamily, Genes Develop., 4, 2353 2365 (1990)

23) Bugge, T. et al. : RXR $\alpha$, a promiscuous partner of retinoic acid and thyroid hormone receptors, EMBO J., 11, 1409 1418 (1992)

24) Landschulz, W. et al. : The DNA binding domain of the rat liver nuclear protein C/EBP is bipartite, Sci. 
ence, 243, 1681 - 1688 (1989)

25) Hillan, K. : Demonstration of rat albumin mRNA in formalin-fixed tissue sections with a DIG-labeled RNA probe, in Nonradioactive In Situ Hybridization Application Manual (1992) Boehringer Mannheim, Germany

26) Kuo, F. et al. : Colocalization in pericentral hepatocytes in adult mice and similarity in developmental expression pattern of ornithine aminotransferase and glutamine synthetase mRNA, Proc. Natl. Acad. Sci. $U S A, 88,9468 \sim 9472(1991)$

27）四童子好広, 武藤泰敏：癌とレチノイド, 臨床検査, 36, 276〜279 (1992) 